\title{
Research paradigm that tackles the complexity of in situ care: video reflexivity
}

\author{
Rick ledema
}

Centre For Team-Based Practice \& Learning in Health Care, King's College London, London, United Kingdom

\section{Correspondence to}

Professor Rick ledema, Centre For Team Based Practice \&

Learning In Health Care, King's College London, London, United Kingdom; rick.iedema@kcl.ac.uk

Accepted 31 August 2018 Published Online First

11 October 2018

\section{SLinked}

- http://dx.doi.org/10.1136/ bmjqs-2017-007728

\section{Check for updates}

(c) Author(s) (or their employer(s)) 2019. No commercial re-use. See rights and permissions. Published by BMJ.

To cite: ledema $R$.

BMJ Qual Saf 2019;28:89-90.
This issue of BMJ Quality \& Safety presents a study conducted at the University of Michigan to evaluate 'video reflexivity' (VR, also referred to as VRE or 'video-reflexive ethnography') as a means for intervening in how physicians and nurses work together. ${ }^{1}$ The study found increased reflection in both nurse and physician participants', an outcome also reported (among other things) in related studies from the UK, Australia, New Zealand and the USA. ${ }^{2-6}$ 'Increased reflection' may not set the hearts and minds of quality and safety experts on fire. And yet this finding is significant.

Consider that healthcare improvement initiatives, patient safety research and system-wide implementation programmes have to come to terms with the implications of rising care complexity. This rise in complexity is due to increasing multimorbidity, mobility and migration, ageing, public assertiveness, technological advances, staff turnover, mounting information, scientific uncertainty, intensifying bureaucratic regulations and rising financial pressures, among many others. These confounders converge on day-to-day care, and they can tear up its routines and plans in an instant. Reflection on how to proceed amidst the resulting complex circumstances enables clinicians to navigate care more effectively-if by reflection we mean not simply a single person reassessing events and past actions in thought, but team members (and patients) collectively exploring and discussing realtime video footage of their own care to reshape practices and practice contexts. This latter process of reflexive deliberation involves people in learning with and from one another about how care works, and about how to convert uncertain, subideal, unstable and often tragic circumstances into mutually agreed ways forward.
Much learning about complex care circumstances is currently achieved through simulation training and workplace participation. In mimicking reality, simulation inevitably imposes some degree of simplification. For its part, workplace participation offers ample opportunities for reflection on complex events, but does not often enough capitalise on these opportunities in practice. Unique about VR is that it takes naturally occurring complexity as its point of departure for learning and improvement. An example of this can be seen in a footage of an infected intensive care unit patient being moved to an isolation room creating numerous infection risks, with staff then being shown reflecting on and learning from the complexity and challenges inherent in this event (see online supplementary materials accompanying: https://innovations.bmj.com/content/1/4/ 157 \# supplementary-materials). ${ }^{6}$

To be sure, complexity poses a huge challenge for how we achieve healthcare quality and safety, and complex events confront us with in situ problems that demand innovative responses. Nevertheless, the quality and safety literature on complexity in healthcare puts its faith into complexity-scientific theoretical principles that are credited with yielding 'understanding' of such complex problems. ${ }^{8}$ This in effect means this literature 'proceed [s] from the 'simple' to the 'complex' (as $17^{\text {th }}$ century 'empiricists' and ideologists like John Locke thought we should and could)' (Wilden, p314). ${ }^{9}$ Its approach to analysis, moreover, sanctions 'the isolation of measurable parts and hence the sacrifice of any genuine commitment to complexity' (Cohn, p42). ${ }^{10}$ Its overall aim is to reduce (care) complexity to 'an object to be viewed or even 'controlled' from an imaginary 'outside" (Wilden, pxxxviii). ${ }^{11}$ 
It is important to acknowledge however that the theorisation of complexity has sought to target phenomena that are difficult if not impossible to anticipate and control. As the gathering point for the various confounders listed above, contemporary care is replete with such complex phenomena. Homing in on care as it happens, VR harnesses in situ manifestations of complex phenomena in the form of real-time video footage for bottom-up learning and intervention. This is not just about asking, what can we learn from reviewing how we just moved four infected patients through the intensive care unit into isolation rooms? It is also asking, although indirectly, how can we become better at reading and negotiating complexity in general? In these ways, VR ensures that participants move 'from the complex to the structures of complexity including their environments' (Wilden, p314). ${ }^{9}$ A burgeoning VR literature now demonstrates that this process skills participants in complexity-sensitive deliberations, complexity-competent modes of learning and complexity-pertinent ways forward. ${ }^{12}$

Given the ubiquity of the visual, it is not surprising that singers, musicians, athletes, teachers and many others now use vision to enhance personal and team performance, and to intervene in their performance contexts. When clinicians review footage of their own work, their attention is drawn to the complexities that become apparent in what they do together: the heady mix of historical, contextual and systemic confounders, the multitude of unacknowledged conditions and unintended consequences, and the host of taken-as-given personal and professional habits and routines. $^{13}$

Indeed, what strikes VR participants is that the footage confronts them with otherwise taken-forgranted behaviours, practices and contexts. They witness themselves accommodating constraints, pursuing preoccupations and enacting routines that on reflection appear at once distant and familiar, puzzling and thoughtless. This defamiliarisation effect is defining of VR: participants learn to ask questions of themselves, of each other, and about their service operations and system contexts. Asking questions is paramount here: it is the strategy par excellence for teams navigating complexity in situ, since posing questions of ourselves, of each other and about our circumstances is precisely what complexity does too. ${ }^{12}$

The foregoing explains why organisations like the Mayo Clinic and Michigan Medicine are turning to VR for strengthening their safety and quality of care.
They recognise the significance of granting front-line actors a front-stage role in reflecting on in situ care complexity and using their experience, insight and questions to rethink clinical processes, service structures and healthcare systems.

Funding The authors have not declared a specific grant for this research from any funding agency in the public, commercial or not-for-profit sectors.

Competing interests None declared.

Patient consent Not required.

Provenance and peer review Commissioned; internally peer reviewed.

\section{REFERENCES}

1 Manojlovich M, Frankel RM, Harrod M. Formative evaluation of the video reflexive ethnography method, as applied to the physician-nurse dyad. BMJ Qual Saf 2019;28:160-6.

2 Lowe DJ, Dewar A, Lloyd A, et al. Optimising clinical performance during resuscitation using video evaluation. Postgrad Med J 2017;93:449-53

3 Collier A, Wyer M. Researching Reflexively with patients and families: two studies using Video-Reflexive ethnography to collaborate with patients and families in patient safety research. Qual Health Res 2016;26:979-93.

4 Hor SY, Iedema R, Manias E. Creating spaces in intensive care for safe communication: a video-reflexive ethnographic study. BMJ Qual Saf 2014;23:1007-13.

5 Neuwirth EB, Bellows J, Jackson AH, et al. How Permanente uses video ethnography of patients for quality improvement, such as in shaping better care transitions. Health Aff 2012;31:1244-50.

6 Iedema R, Hor S, Wyer M. An innovative approach to strengthening health professionals' infection control and limiting hospital acquired infection: video-reflexive ethnography. BMJ Innov 2015.

7 Prasad V, Vandross A, Toomey C, et al. A decade of reversal: an analysis of 146 contradicted medical practices. Mayo Clin Proc 2013;88:790-8.

8 Braithwaite J. Changing how we think about healthcare improvement. BMJ 2018;361:k2014.

9 Wilden A. The rules are no game: the strategy of communication. London: Routledge \& Kegan Paul, 1987.

10 Cohn S, Clinch M, Bunn C, et al. Entangled complexity: why complex interventions are just not complicated enough. $J$ Health Serv Res Policy 2013;18:40-3.

11 Wilden A. System and structure: essays in communication and exchange. London: Tavistock, 1980.

12 Iedema R, Carroll K, Hor S. Video-reflexive ethnography in healthcare research and healthcare improvement. Abingdon: Taylor \& Francis in press, ..

13 Iedema R, Mesman J, Carroll K. Visualising health care improvement: innovation from within. Oxford, UK: Radcliffe, 2013. 